\title{
Research
}

\section{An Empirical Analysis of the Social and Ecological Outcomes of State Subsidies for Small-Scale Fisheries: A Case Study from Chile}

\author{
$\underline{\text { Carolin I. Mondaca-Schachermayer }}^{1}, \underline{\text { Jaime Aburto }}^{1}, \underline{\text { Georgina Cundill }}^{2}, \underline{\text { Domingo Lancellotti }}^{3}$, \\ $\underline{\text { Carlos Tapia }}^{4}$, and Wolfgang Stotz ${ }^{1}$
}

\begin{abstract}
Small-scale fisheries, which are often associated with low levels of income and poor infrastructure, receive substantial funding from governmental institutions worldwide. Very few empirical studies have explored the outcomes of these investments for people and ecosystems. This paper presents the findings of a study aimed at assessing the social and ecological outcomes of government subsidies for small-scale fisheries through an analysis of 32 fishing villages, referred to as caletas, in Chile over a 12year period. Findings suggest that the funding appears to be higher for those caletas with the highest value landings and is unrelated to socioeconomic need or poverty; that caletas in rural areas receive less investment than their urban counterparts; that funding did not lead to a positive improvement in either the landings or income for fishers; and, finally, that funding appears to be a consequence of, rather than a reason for, the ecological and productive history of fisheries. These findings challenge two assumptions informing the debate about subsidization in small-scale fisheries: first, that subsidization will lead to over-exploitation, and second, that subsidies are supplied to alleviate poverty.
\end{abstract}

Key Words: Chile; small-scale fisheries; subsidies

\section{INTRODUCTION}

Small-scale fisheries have long been associated with low levels of income, marginality (FAO 1974, Béné 2003), and lack of basic needs (Allison and Horemans 2006). A variety of factors have been identified that contribute toward this. First, smallscale fisheries are often unregulated and therefore at times exhibit characteristics associated with open access resource regimes (Berkes and Jolly 2001), where an ever increasing number of fishermen make use of a limited resource, leading to decreasing income (Béné 2003). Small-scale fisheries are also frequently geographically isolated in rural areas, with access to very basic infrastructure, which together prevent development (Smith 1979, Panayotou 1982, Pauly 1997, Squires et al. 1998, Gibson and Rozelle 2003). Small-scale fishermen are also frequently regarded as politically voiceless and disorganized (Béné 2003). This, along with vulnerability, is a well-recognized characteristic of multidimensional poverty (Sen 1999, Béné 2003, 2009).

In response to this recognition, governments worldwide have sought to develop small-scale fisheries in various ways. One approach has been to impose greater regulations on resource extraction, thereby ensuring an ongoing flow of resources and making the livelihoods linked to those resources more sustainable (Johannes 2002, Leiva and Castilla 2002, Defeo and Castilla 2005). Another approach, sometimes in unison with the former, but often not, has been to subsidize small-scale fisheries (Squires et al. 1998, Allison and Ellis 2001, Kaczynski and Fluharty 2002, Abdallah and Sumaila 2007). A subsidy is broadly defined as a government transfer by which a benefit is conferred (Grynberg 2003, Schrank 2003) and, in addition to direct monetary transfers, may be in the form of research and education. The desired outcomes of this subsidization are generally twofold: to alleviate

\footnotetext{
Grupo de Ecología y Manejo, Facultad de Ciencias del Mar, Universidad Católica del Norte, ${ }^{2}$ Centro de Estudios Avanzados en Zonas Aridas (CEAZA),

${ }^{3}$ Departamento de Salud Pública, Facultad de Medicina, Universidad Católica del Norte, ${ }^{4}$ Universidad de La Serena
} 
poverty and to increase the sustainability of the fishery.

However, many analysts argue that subsidies too often lead to fleet modernization, increased catches, resource depletion, and ultimately decreased sustainability (Milazzo 1998, Pauly et al. 2002, Khan et al. 2006, OECD 2006, Jacquet and Pauly 2008). A recent empirical analysis of the effects of subsidies on industrial fisheries in Japan has shown that, under an appropriate management system, subsidies do not necessarily lead to unsustainable increases in production (Yagi et al. 2009). Despite a pervasive assumption in the literature that negative outcomes are to be expected from subsidies in smallscale fisheries (Andrade 1997, Allison and Ellis 2001, Pauly et al. 2002), a similar empirical analysis has not been conducted. Another untested assumption associated with subsidies in small-scale fisheries is that subsidies can have positive outcomes under the 'right' conditions. Subsidy schemes that are based on incentives and supported by ongoing research, monitoring, and oversight, for example, are expected to lead to improved outcomes (Grafton et al. 2006). Similarly, subsidy schemes that are accompanied by management plans are expected to lead to more sustainable outcomes (Abdallah and Sumaila 2007). Currently, however, there is a lack of literature dealing with the results of monitoring and evaluation processes linked to subsidized fisheries, which makes it very difficult to accurately define the positive or negative outcomes of subsidies for small-scale fisheries and under what conditions these outcomes might be expected.

This paper seeks to address this gap to some extent by exploring empirical evidence of the outcomes of government subsidies for small-scale fisheries in Chile, a country with some of the most productive fisheries in the world due to the greater Humboldt Current (Aguilar 2000, Agüero 2007) and where small-scale fisheries are subject to territorial user rights management schemes (Gelcich et al. 2005, 2007, 2008). A necessary question to address before such an analysis could take place, however, was: outcomes for whom? Analyses of small-scale fisheries have been criticized for focusing on either the ecological or the social domain of fisheries (Béné 2003). In South and Central America in particular, analyses have been criticized for focusing too heavily on the ecological domain at the expense of exploring the socioeconomic factors that drive change in small-scale fisheries (Salas et al.
2007). Small-scale fisheries are tightly linked social-ecological systems where outcomes for one part of the system (for example, stock depletion) in the ecological domain have implications for other parts of the system (for example, livelihoods) in the social domain and vice versa (Berkes et al. 2003). Small-scale fisheries are also part of complex systems characterized by nonlinearity and emergence (Berkes and Folke 1998), which implies that linear relationships between 'inputs,' such as subsidies, and 'outputs,' such as poverty alleviation and ecological sustainability, should not be taken for granted. This characteristic of small-scale fisheries makes an analysis of the relationship between subsidies and the productive trends in fisheries important but challenging to achieve in practice. We attempt such an analysis based on available information over a 12-yr period in Chile, where the objective of subsidies has been to develop the fishery and alleviate poverty. We analyze empirical evidence of where money was invested by the state (inputs) and the relationship between subsidies received and the productive trends of the fisheries (outputs).

Small-scale fisheries in Chile offer a useful case study for understanding the relationships between subsidies and productive trends. As in many other parts of the world, for example, Mexico (Hernandez and Kempton 2003) and some parts of Africa (Béné 2009), small-scale fisheries in Chile consist of highvalued resources, and production is therefore linked to international markets (Gallardo 2008). Market forces drive the development of these small-scale fisheries, stimulating the discovery of new resources, developing new markets, and influencing prices. Some subsidies in Chile may be linked to improved management, as may be the case of the Turf system (Gelcich et al. 2005), which has been greatly subsidized in its implementation, but others are not. As in other parts of the world, a direct analysis of the influence of subsidies on the number of fishers (the effort) is confounded by a lack of reliable data on the movement dynamics of fishers in and out of the activity, or along the coast.

\section{STUDY AREA AND METHODS}

\section{Study site}

Chile's IV Region, referred to as the Coquimbo Region, is regarded as one of the most important small-scale fishery regions in the country (Montoya 
2002) (Fig. 1) and was therefore selected for this study. The Coquimbo region has 4809 officially registered fishermen in the National Fisheries Service Register and contains 32 fisher villages, referred to as "caletas," where fishermen dock their boats and land their catches. In Chile, some caletas are located on private land, but access to fishing is assured by Chilean law. However, no infrastructure, such as piers, can be installed by the government on private land. Chile is divided into 15 regions, which in turn are subdivided into provinces. The region of Coquimbo consists of three provinces: Limarí, Choapa, and Elqui, the regional capital (La Serena) being located in the Elqui province. Most of the caletas in Limarí $(75 \%)$ and Choapa $(50 \%)$ are located on private land.

\section{Data collection}

\section{Investment data}

In order to determine the amount of subsidies in small-scale fisheries in the region, and the relationship between investment, landings, and the value of landings, data were collected covering a 12-yr period (between 1996 and 2007) for all 32 caletas in the region. Data for the years 2000 and 2001 were excluded because they were incomplete. The first step was to identify and group funding sources according to their chief objective (summarized in Table 1) based on official reports from the National Fisheries Service (Soto 2002, Chavéz and Tirado 2008) of funding institutions. Funding was grouped into two categories: infrastructure projects and others; "others" included funding for fishing equipment, production, TURFs (territorial user rights fishery), research, and social programs. The monetary values invested by each institution each year between 1996 and 2007 were corrected to their value in December $2008^{[1]}$ and transformed into U.S. dollars based on the mean exchange rate for the same month (1 US $\$=629.11$ CLP).

\section{Landings data}

The second step was to collect data on landings (recorded in tons) from 1996 to 2007, which were obtained from the National Fisheries Service. Resources were grouped into major categories (fishes, squid, invertebrates, and seaweed).

\section{Value of landings data}

Because data on the monetary value of the landings were unavailable, the sanction value ${ }^{[2]}$ on each resource was used to obtain the value of the landings.

\section{Income data}

Because data on per capita income per fisherman was unavailable, income was calculated by dividing the value of the landing by the number of fishermen officially registered in each of the 32 caletas. Once again, the monetary values of landings for each year between 1996 and 2007 were corrected to their value in December 2008 and transformed into U.S. dollars based on the mean exchange rate for the same month $(1 \mathrm{US} \$=629.11 \mathrm{CLP})$.

\section{Data analysis}

A linear regression was performed to answer the following questions: Is more money invested in areas where landings are greater? And/Or, is more money invested in the poorest areas? In order to answer the first question, we plotted the average annual funding versus the average annual landings, and for the second question, we plotted the average annual per capita funding versus the average annual per capita income. This analysis was performed twice because three caletas (Coquimbo, Guayacán, and Tongoy) skewed the outcomes of the regression because the largest subsidies were concentrated in these caletas.

In order to identify changes in landings and incomes, a regression analysis was performed on the data for the categories previously described from each caleta. The general trend is identified based on the slope of the regression of the variables versus time. Trends were then classified according to the slope of the regression: a positive slope (slope $>1$ ) was classified as an "increase"; a slope close to $0(-1<$ slope > 1) as "no change"; and a negative slope (slope $<-1$ ) as a "decrease." The data were plotted on a chart.

A nonmetric multidimensional scaling analysis (nMDS) (Clarke and Warwick 1994) was conducted to detect relationships between (1) the characteristics of each caleta, which were (a) types of fisheries (fishes, squids, seaweed, and invertebrates), (b) numbers of fishers, and (c) type of caleta (rural or 
Fig. 1. Location of the Coquimbo Region (Region IV) in Chile and its administrative division. The photographs show examples of "Caletas," which are the landing sites of artisanal fisheries. (A) Caleta Sierra and (B) Caleta Totoralillo Sur.
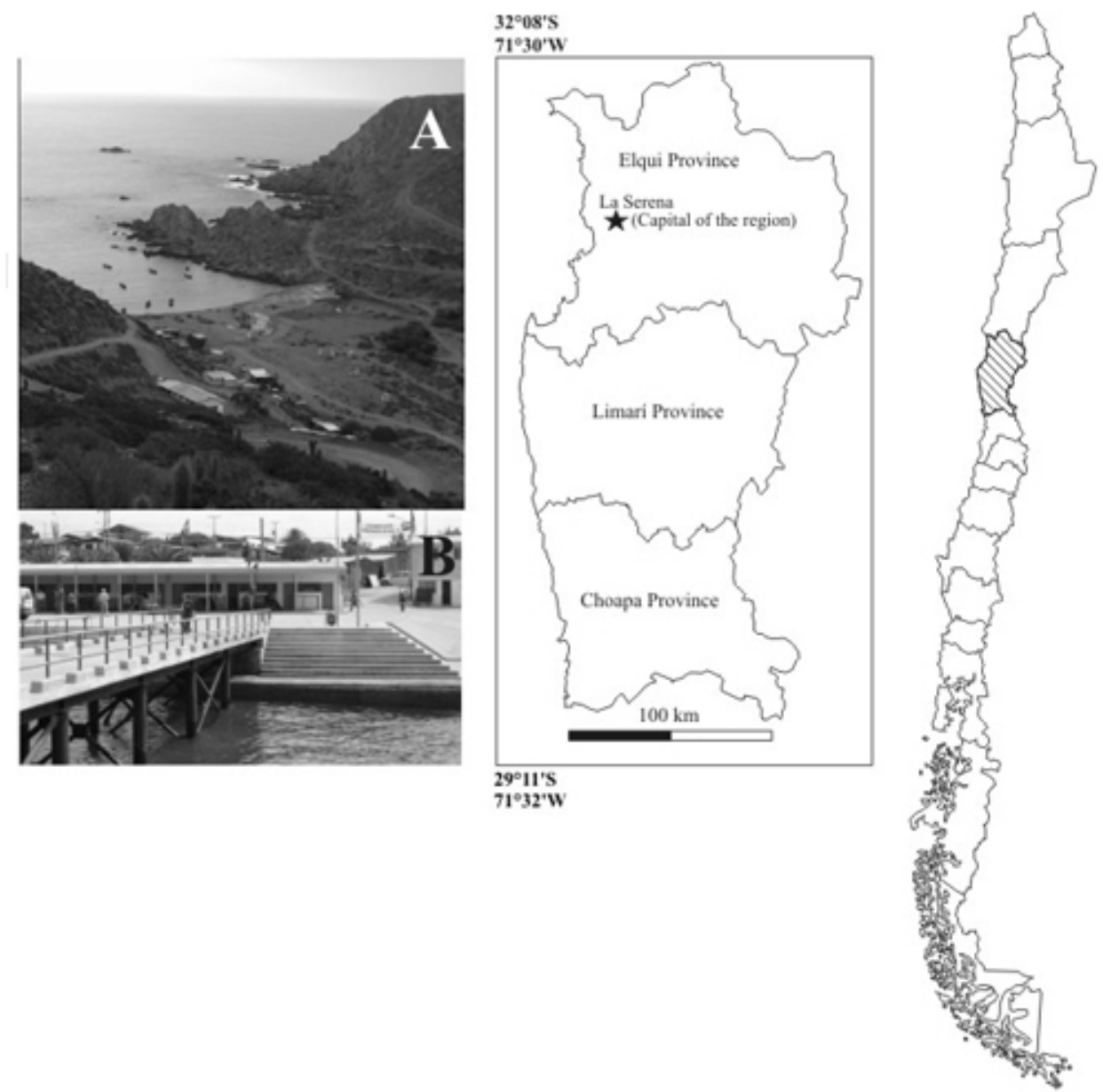

urban); (2) funding; and (3) trends(changes over time) in landings and income.

A weighted Spearman rank correlation coefficient was used to establish the correlation between the different data sets (funding vs. characteristics, funding vs. trends, characteristics vs. trends), using the dissimilarity matrices of nMDS analysis. Statistical significance was established using a randomization (permutation) test at a $\mathrm{P}=0.05$.

\section{RESULTS}

\section{Subsidies for small-scale fisheries}

A total of 25.55 million US\$ was spent on funding diverse projects and programs, distributed as follows: infrastructure and equipment $74 \%$, and "others" that include production 9\%, social programs $15 \%$, research $1 \%$, and TURFs $1 \%$, for specific caletas in the Coquimbo Region over the $12-y r$ period. The average annual funding (2.55 million US\$) represents $48 \%$ of the average annual value of regional landings. When considered on a per capita basis (equating to 454 US\$), this sum 
Table 1. Institutions that funded development programs or actions and research during the period 19962007 in the Coquimbo Region, Chile.

Institution (with its original Spanish name and its translation) Actions funded

Fondo de Fomento de la Pesca Artesanal (FFPA)

Fund for the Promotion of Artisanal Fisheries

Fondo Nacional de Desarrollo Regional (FNDR)

National Fund for the Regional Development

Corporación de Fomento de la Producción (CORFO)

Corporation for the Promotion of Production

Servicio Nacional de Empleo y Capacitación (SENCE)

Nacional Service for Employment and Training

Fondo de Solidaridad e Inversión Social (FOSIS)

Solidarity and Social Investment Fund

Dirección de Obras Portuarias (D.O.P.)

Direction for Port Constructions

Fondo de Investigación Pesquera Fisheries Research Fund

Programa Más Región

(an EU-funded program for the regional development)
Co-finances diverse projects fishermen organizations want to develop (equipment, restocking, aquaculture, marketing, processing, etc.)

Finances infrastructure for the social and economic development of the region

Finances baseline studies and monitoring of management areas (a system of territorial user rights for benthic fisheries)

Finances educational activities that seek to improve labor and employment

Finances projects, programs, and activities for poverty alleviation

Finances the construction and maintenance of port and coastal infrastructure

Funds fisheries research

Financed small productive initiatives for artisanal fisheries, promoting the establishment mini-enterprises represents $59 \%$ of the annual average income of an artisanal fisherman in the region. In addition to this funding, regional funding initiatives totaled 9.64 million US \$ during the same period. This funding was targeted at artisanal fishermen but not at specific caletas.

The funding shows a very unequal geographic distribution, with $76 \%$ of the funding spent in just one province (Elqui Province, in which the capital of the region is located). Within each of the three provinces that form part of the Coquimbo Region, the same pattern of unequal distribution was observed, with some caletas receiving much more funding than the others (Fig. 2B). This pattern of unequal distribution was still observed when the funding was standardized to an average annual per capita funding (Fig. 3B), thus suggesting that unequal distribution of funding among caletas is not related to their size, as expressed in terms of the number of fishermen that belong to each one. The comparison between rural and urban caletas located on state-owned land with those located on private land suggests that property regimes play the most important role (Figs. 2B and 4). Caletas located on private property receive almost no funding for infrastructure, which is the major item in caletas located on state-owned land, regardless of their urban or rural character (Fig. 4A). In addition, the relationship between the proximity to urban centers plays an important role. Fig. 4 depicts funding in the caletas located between 10 and $30 \mathrm{~km}$ from urban centers and illustrates the case of Tongoy (Fig. 4B, see $*$ ), which is a caleta were a lot of money ( $60 \%$ of the total) is invested in the scallop industry. When this is taken into account, the distribution of funding in the region is very even, with the exception of the caletas near urban centers (Fig. 4).

On the other hand, contrary to the expectation that funding would be skewed toward caletas exhibiting the highest level of poverty and underdevelopment, funding is higher for those caletas whose landings exhibit the highest values (Fig. 2A). A positive relationship was found between the amount of funding received and the value of total landings $\left(r^{2}=\right.$ 
Fig. 2. Distribution of average annual landing (A) and average annual funding (B) for each of the caletas in Coquimbo Region during 10 years in the period 1996-2007. Landing (A) is separated by resource, and funding (B) is separated by funding lines. In (B), the type of caleta is indicated: $R=$ rural; $R P=$ rural located on privately owned land; $U=$ urban. For Coquimbo, the represented fish landings have to be multiplied by 10 .

Value of average annual landing (thousand USS)

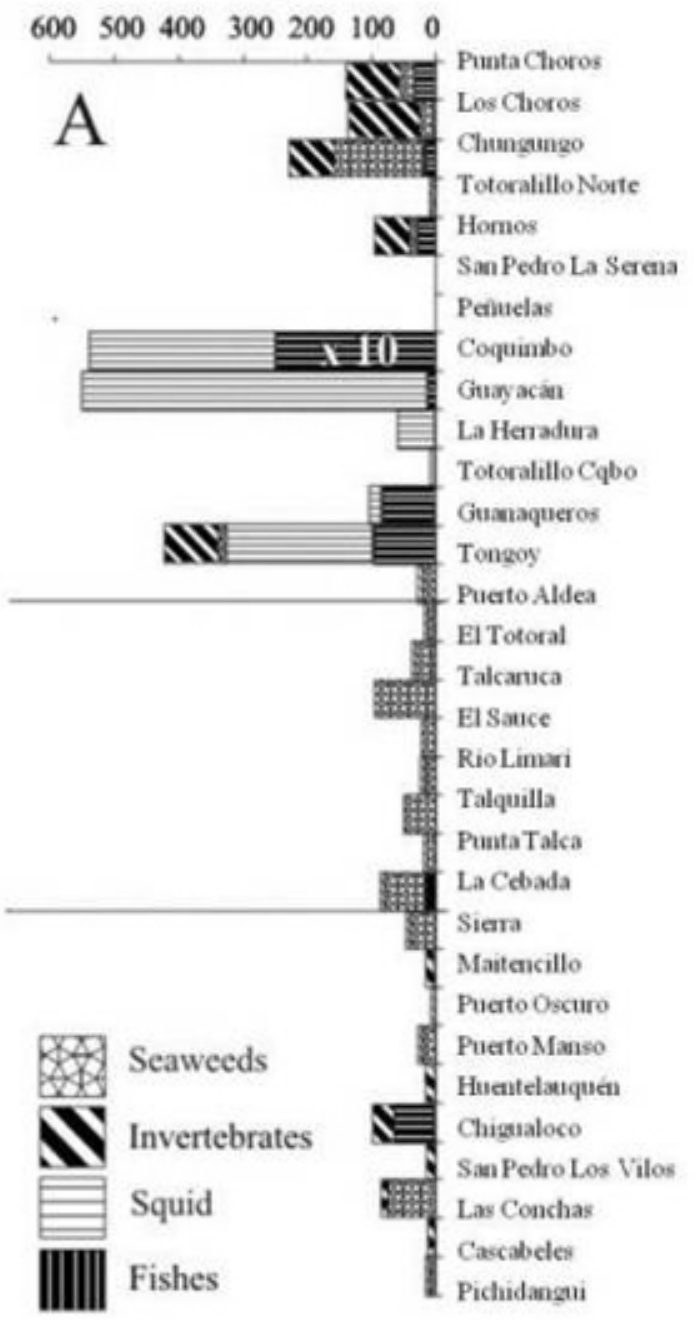

Average annual Funding (thousand USS)

$\begin{array}{lllllll}0 & 100 & 200 & 300 & 400 & 500 & 600\end{array}$

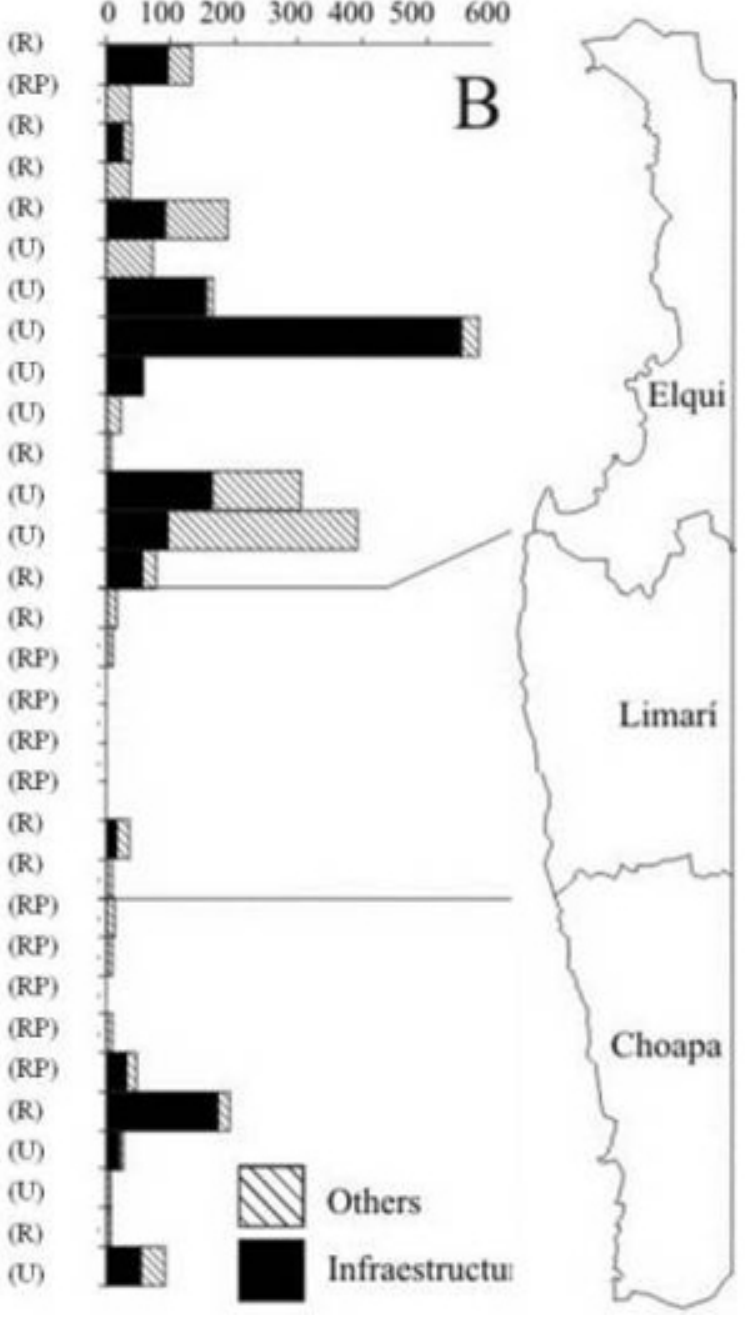

0.57) (Fig. 5A). However, this is influenced by those caletas in the Elqui province (Coquimbo, Guayacán, and Tongoy) that exhibit the greatest landings. When controlling for these higher-income caletas, no relationship was found between funding and income $\left(\mathrm{r}^{2}<0.01\right)$ (Fig. 5A and B). Those caletas that received the most funding are within or close to the major urban centers of each province, whereas those with less investment tend to be rural caletas.
Over the 12-yr period of interest here, the majority of the funding went into port infrastructure, such as piers and storage spaces (Figs. 2B and 3B). The second funding line was social programs, which included roads, health care, electricity, drinking water, and schools. These also tended to be concentrated in caletas closer to urban areas in just one province (Elqui). 
Fig. 3. Distribution of average annual per capita income (A) and of average annual per capita funding (B) for each of the caletas in Coquimbo Region during 10 years in the period 1996-2007. Income (A) is separated into the resource group producing it, and funding $(\mathrm{B})$ is separated by funding line. In brackets, the number of fishers for each caleta is indicated.

Average annual per capita income (USS)

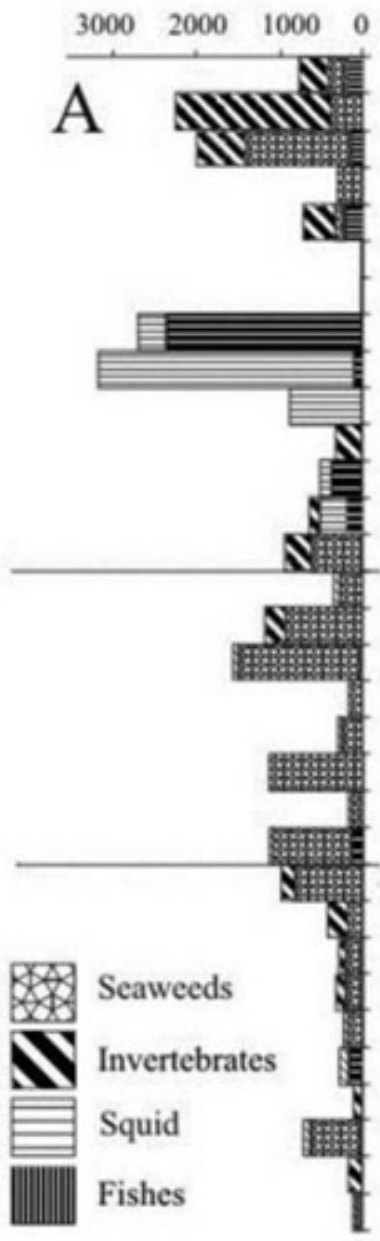

PuntaChoros (189)

Los Choros

Chungango

Totoralillo Norte

Homos

San Pedro La Serena (188)

Penuelas

Coquimbo

Guayacan

La Herradura

Totoralillo Cqbo

Guanaqueros

Tongoy

Puerto Aldea

E1 Totoral

Talcanuca

El Sance

RioLimari

Talquilla

Punta Talca

La Cebada

Sicra

Maitencillo

Puerto Oscuro

Pueto Manso

Huantelauquén

Chigualoco

San Pedro Los Vilos (101)

Las Conchas

Cascabeles

Pichidangui
(62)

(114)

(32)

(133)

(227)

(1072)

(177)

(63)

(55)

(223)

(658)

(33)

(38)

(31)

(62)

(117)

(77)

(46)

(104)

(78)

(35)

(29)

(98)

(76)

(353)

(114)

(113)
Average annual per capita funding

(USS)
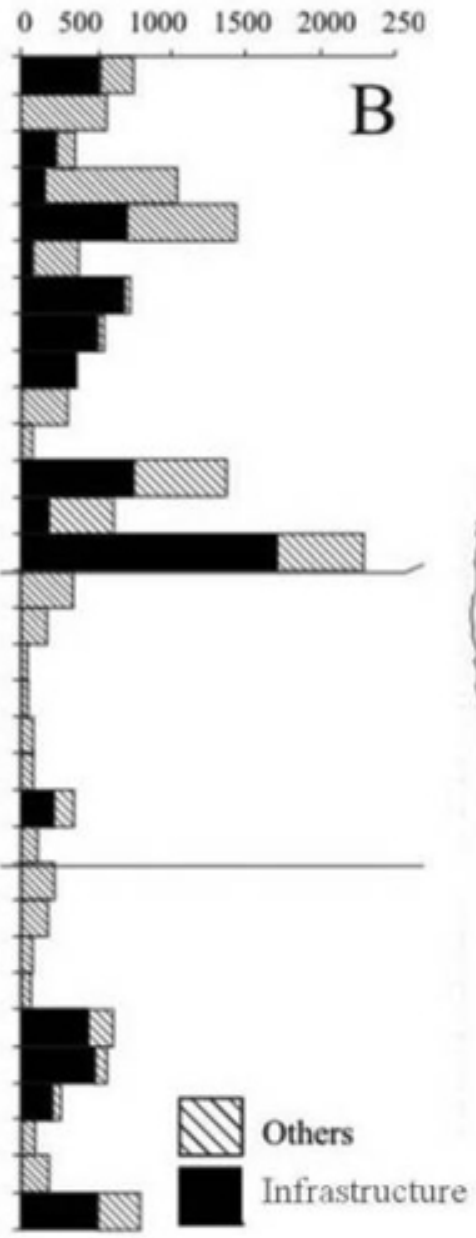

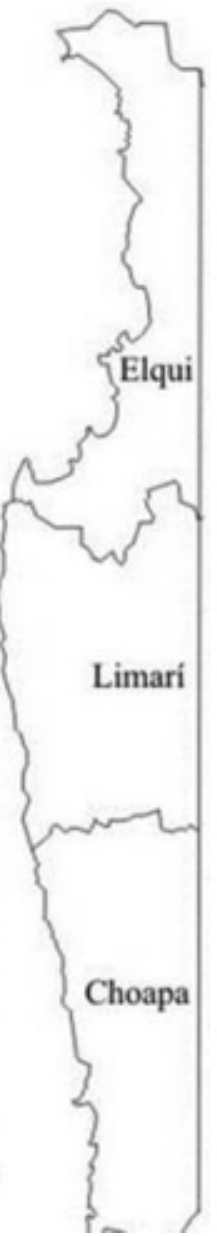

\section{Social and ecological impacts of subsidies}

Each caleta has its own social-ecological characteristics, which influence its productive history and change over time. No relationships were found between per capita funding and per capita income (Fig. 5C and D). The irregularities in the performance of the variables measured over time have been significant. For example, in most cases, trends of per capita income produced by landings of seaweed and invertebrates tended to be decreasing, whereas those caletas that relied on fishes and giant squid pointed to a more stable pattern, with few caletas indicating decreasing in their landings and consequently income (Fig. 6). This confirms that changes in the variables over time are very different in the caletas.

Funding seems to produce no effect on these changes or differences. This suggestion is corroborated by a comparison between individual caletas. For example, if we compare Coquimbo with 
Fig. 4. Investment according to proximity to administrative centers for (A) infrastructure investments and $(\mathrm{B})$ other investments. *, the investment in Tongoy.
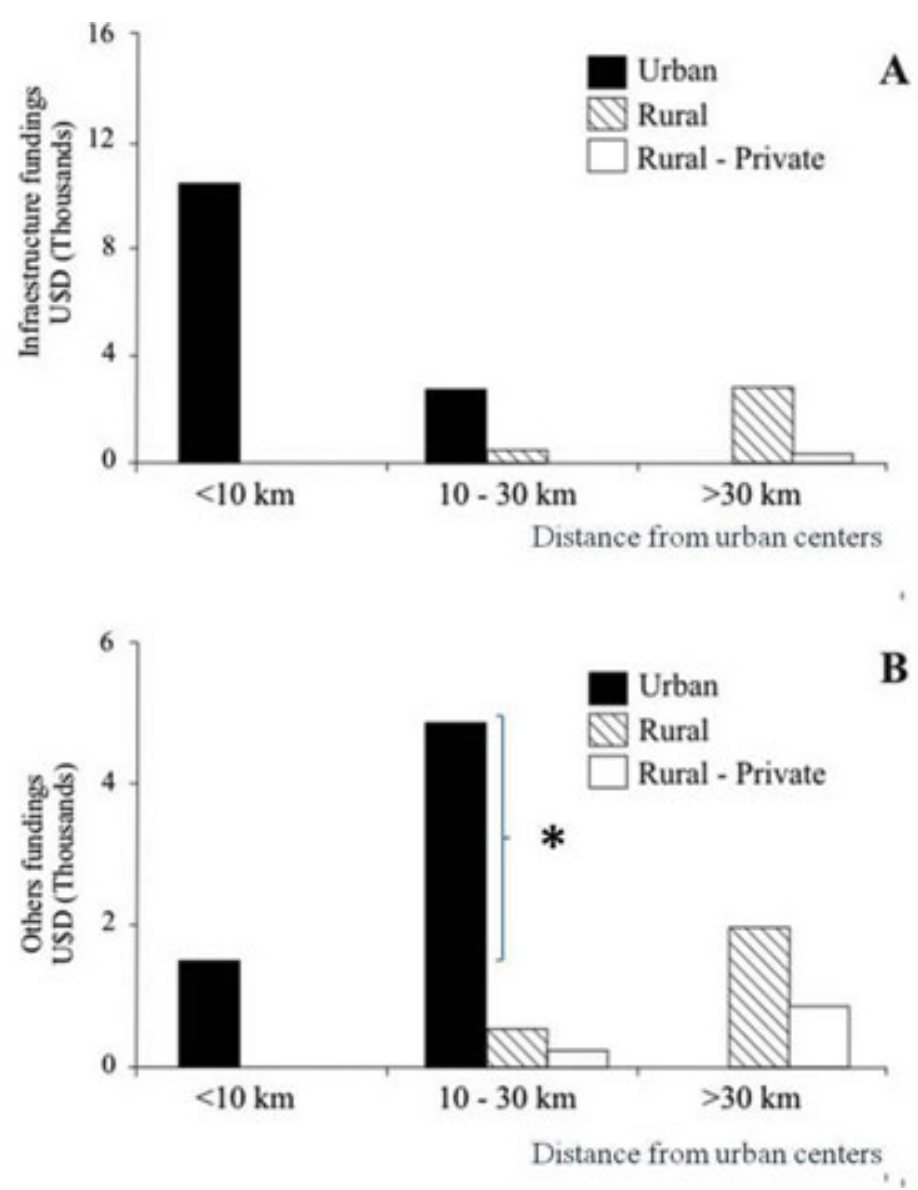

Guayacan, which are both related to the urban center of Coquimbo, we observe that the first receives much more funding (Figs. 2B and 3B), but both exhibit very similar trends (Fig. 6). The same can be observed for other comparable pairs of caletas: El Totoral and Punta de Talca, both rural caletas; Talcaruca and El Sauce, also rural caletas; or Las Conchas and Pichidangui, both urban caletas. In all these cases, one received much more funding than the other, but no differences in trends were discernable.

Nevertheless, no direct relationship was found between these changes in landings or income and the amount of funding received $\left(\mathrm{r}^{2}=0.0268\right.$ for trends in landings vs. funding; $\mathrm{r}^{2}=0.0462$ for trends in income vs. funding; Table 2). From the analysis of clusters by nMDS of the three variables (characteristics of the caletas, funding, and trends), spatial patterns suggest some relationships (Fig. 7AC). First, changes over time in landings and income are more related to the productive characteristics of the caleta (Fig. 7B and C) than to the funding they received (Fig. 7A). Second, the grouping related to funding has similarities to the grouping related to productive characteristics. For example, those caletas whose productive activity is mainly based on fish and squid appear together in the group that is characterized as receiving the most funding for infrastructure (Fig. 7A and B). The nMDS supported the finding that there is no relationship between funding received and the productive characteristics of caletas. 
Fig. 5. Relation between average annual funding and landing (A, B) and per capita income and per capita funding (C, D) of the caletas in the Coquimbo Region.
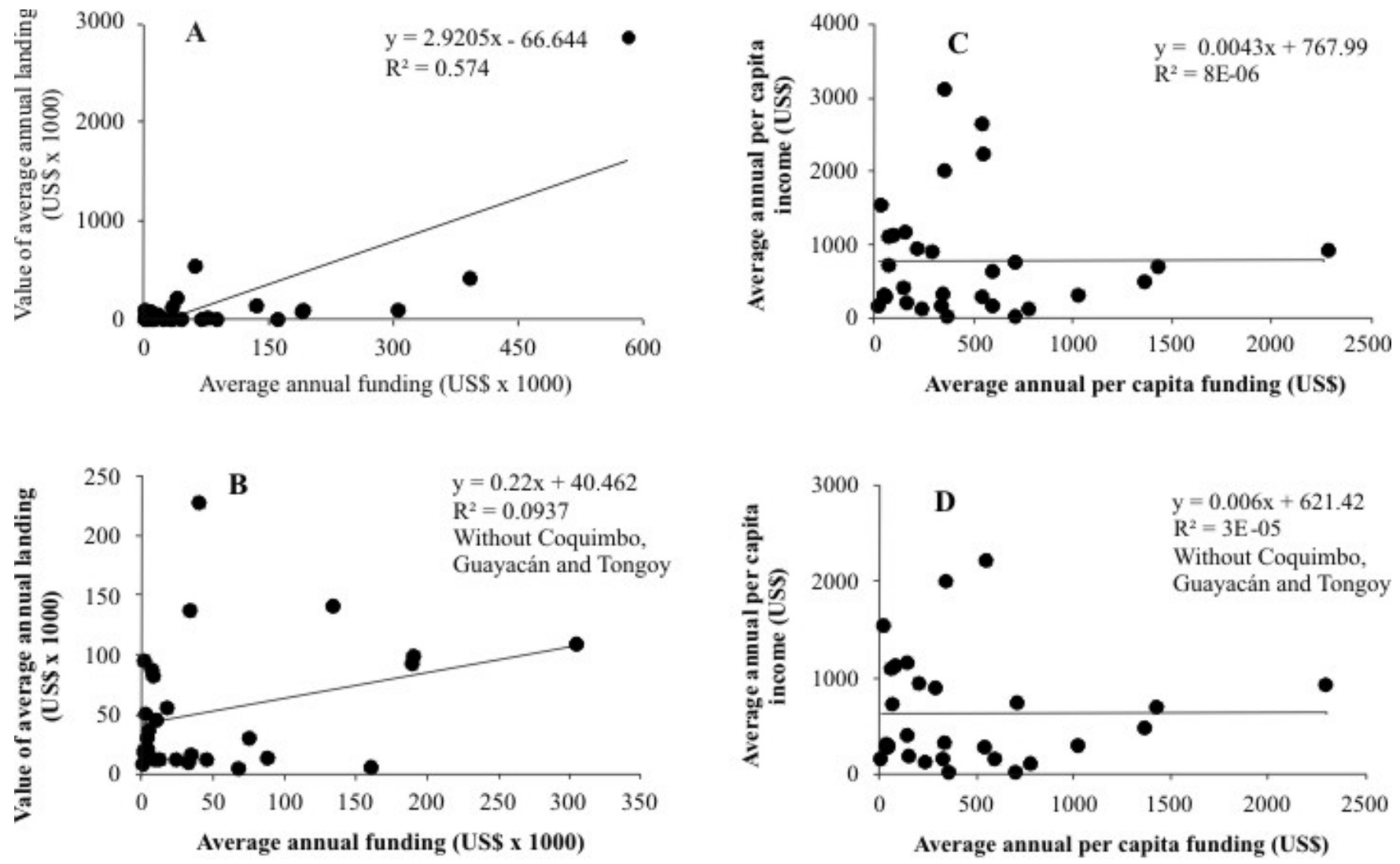

A Spearman rank order correlation analysis confirmed the finding that change in the caletas is related to their ecological and productive characteristics, rather than to the subsidies they have received (Table 2). In addition, funding appears better related to productive characteristics than to their trends (Table 2), thus suggesting that funding is more a consequence of, than a reason for, the productive history of each caleta. Funding seems to produce almost no effect. This suggestion can be also corroborated by the comparison between individual caletas.

\section{DISCUSSION}

The findings presented here challenge two salient assumptions that inform scientific understanding of the outcomes of subsidies for small-scale fisheries.
The first of these assumptions is informed by economic arguments and suggests that subsidies will necessarily lead to over-exploitation and resource depletion. In this study, however, despite subsidies of up to $59 \%$ of the per capita income of fishermen, the size of landings and the income received did not change significantly over a $12-\mathrm{yr}$ period. Indeed, the proportion of subsidies compared with income was more than double that estimated by other authors working at global scales who have predicted over-exploitation as a result of subsidies (Milazzo 1998). A similar study conducted in Japan concluded that state subsidies did not lead to either an increase or a decrease of prices or numbers of fishers or vessels. The authors argue that, under effective management, subsidies do not necessarily cause production increases or negatively impact fishing stock (Yagi et al. 2009). 
Fig. 6. Changes of the per capita income produced by the different resources landed in each caleta. Resources: Fi, fishes; Sq, squid; Sw, seaweed; In, invertebrates. The general trend is identified based on the slope of the regression of income versus time.

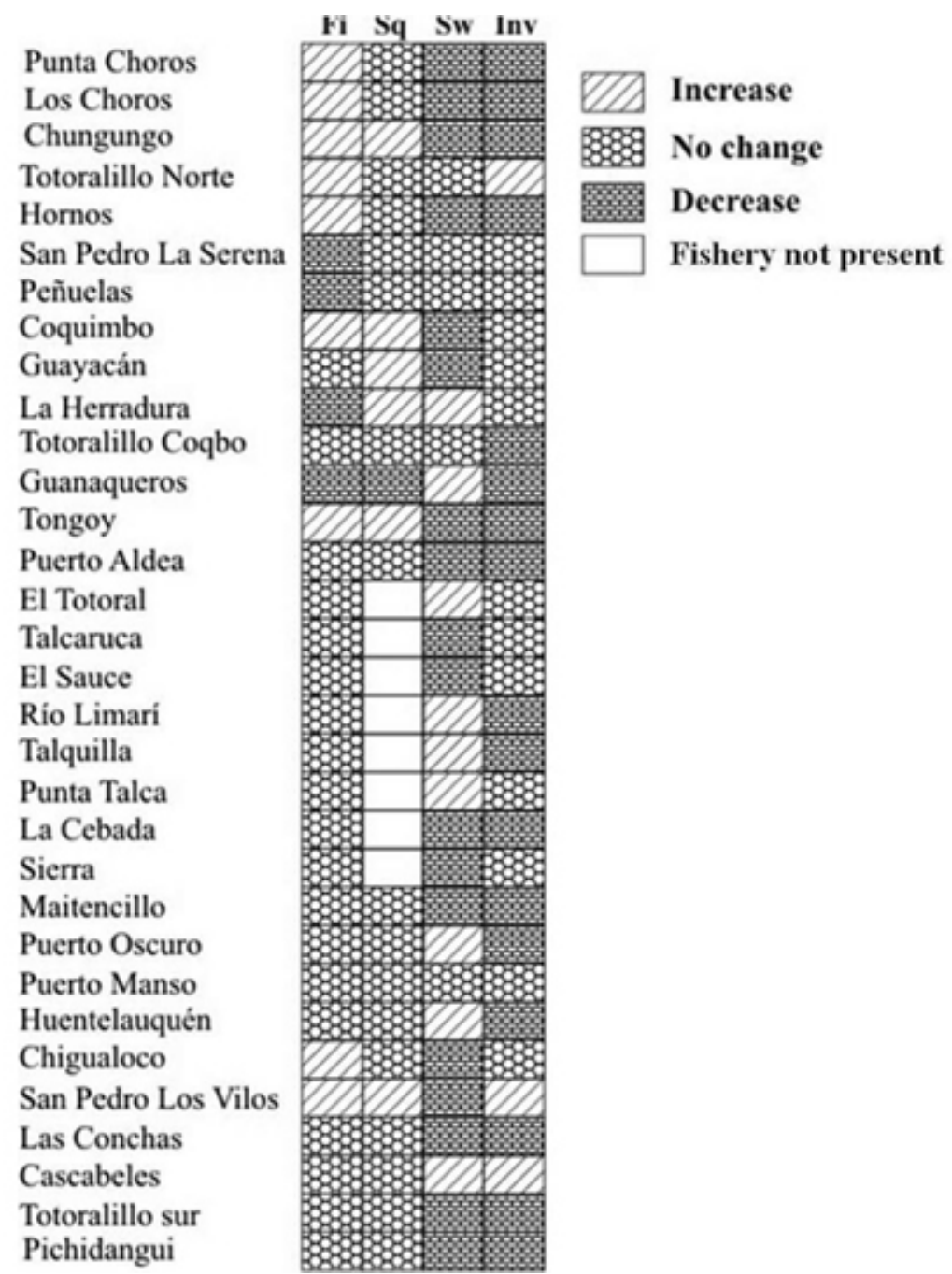

In addition to understanding the management regimes associated with subsidies, a more nuanced understanding of different kinds of subsidies seems also to be necessary. In the fisheries considered here, the subsidies given were aimed at improving working conditions for fishermen, through better ports, better piers, better storage capacity, access to drinking water, electricity, better roads that connect landing places to markets, and so on, rather than investing in bigger boats and bigger nets. These kinds of subsidies result in improved working conditions for fishermen but do not necessarily influence fishing efficiency and should perhaps receive a fairer hearing within scientific and policy forums. Seemingly, better working conditions or improved access has not been an incentive for new people to move into the activity, as observed in the past (Meltzoff et al. 2002), a point that needs more analysis and attention to be properly understood.

The second assumption challenged by this study is that governments provide subsidies to alleviate poverty and marginality (Smith 1979, Pauly 1997, Squires et al. 1998, Allison and Ellis 2001, Béné 
Table 2. Results of the Spearman rank order analysis, analyzing similarities between funding lines (funding), productive characteristics (characteristics), and the changes of landings and income (trends).

\begin{tabular}{|c|c|c|c|}
\hline Group of caletas analyzed & Variables & $\mathrm{R}$ & $\mathrm{P}$ \\
\hline \multirow[t]{3}{*}{ All caletas } & Funding vs. characteristics & 0.29 & $* * *$ \\
\hline & Funding vs. trends & 0.29 & $* * *$ \\
\hline & Characteristics vs. trends & 0.15 & $* * *$ \\
\hline \multirow[t]{3}{*}{ Caletas related to urban centers } & Funding vs. characteristics & 0.27 & NS \\
\hline & Funding vs. trends & 0.48 & $* * *$ \\
\hline & Characteristics vs. trends & 0.7 & $* * *$ \\
\hline \multirow[t]{3}{*}{ Rural caletas } & Funding vs. characteristics & 0.66 & $* * *$ \\
\hline & Funding vs. trends & 0.13 & $*$ \\
\hline & Characteristics vs. trends & 0.58 & $* * *$ \\
\hline \multirow[t]{3}{*}{ Caletas established on state-owned land } & Funding vs. characteristics & 0.52 & $* * *$ \\
\hline & Funding vs. trends & 0.47 & $* * *$ \\
\hline & Characteristics vs. trends & 0.66 & $* * *$ \\
\hline \multirow[t]{3}{*}{ Caletas established on privately owned land } & Funding vs. characteristics & 0.51 & $* * *$ \\
\hline & Funding vs. trends & 0.58 & $* * *$ \\
\hline & Characteristics vs. trends & 0.79 & $* * *$ \\
\hline
\end{tabular}

$* \mathrm{P}<0.05, * * \mathrm{P}<0.01, * * * \mathrm{P}<0.001, \mathrm{NS}$ not significant

2003, Grynberg 2003, Salas et al. 2007). Here, no relationship was found between poverty and where subsidies were invested. Proximity to urban centers and the value of landings already taking place seemed to be the defining characteristics of those caletas that received subsidies. Similar trends have been found in other parts of the country, where fishermen openly recognize that nearness to urban centers plays a critical role in determining their access to government subsidies (Medina et al. 1997). Another important factor influencing these results is that the Chilean government does not provide subsidies for caletas located on private land. Around the world, small-scale fishermen are losing access to fishing grounds due to demands for prime land along the coast. In Chile, although law protects the rights of fishermen to access the coast, they lose access to subsidies because they are prevented from building infrastructure. Because of this, the incentive to move and fish in remote areas is prevented, instead generating an ever-increasing concentration in urban areas, in which subsidies in fact improve working conditions. This trend of focusing subsidies in urban areas, at the expense of their rural counterparts, is often politically motivated as constituencies are concentrated in these areas, and it is unlikely to be unique to Chile. Where the intention behind subsidies is poverty alleviation, as is often the case with small-scale fisheries, these findings suggest that rural fisheries require special attention. 
Fig. 7. Nonmetric multidimensional scaling (nMDS) of funding characteristics (A), characteristics of each caleta (B), and the trends of production and income $(\mathrm{C})$. The vectors show the direction of changes.
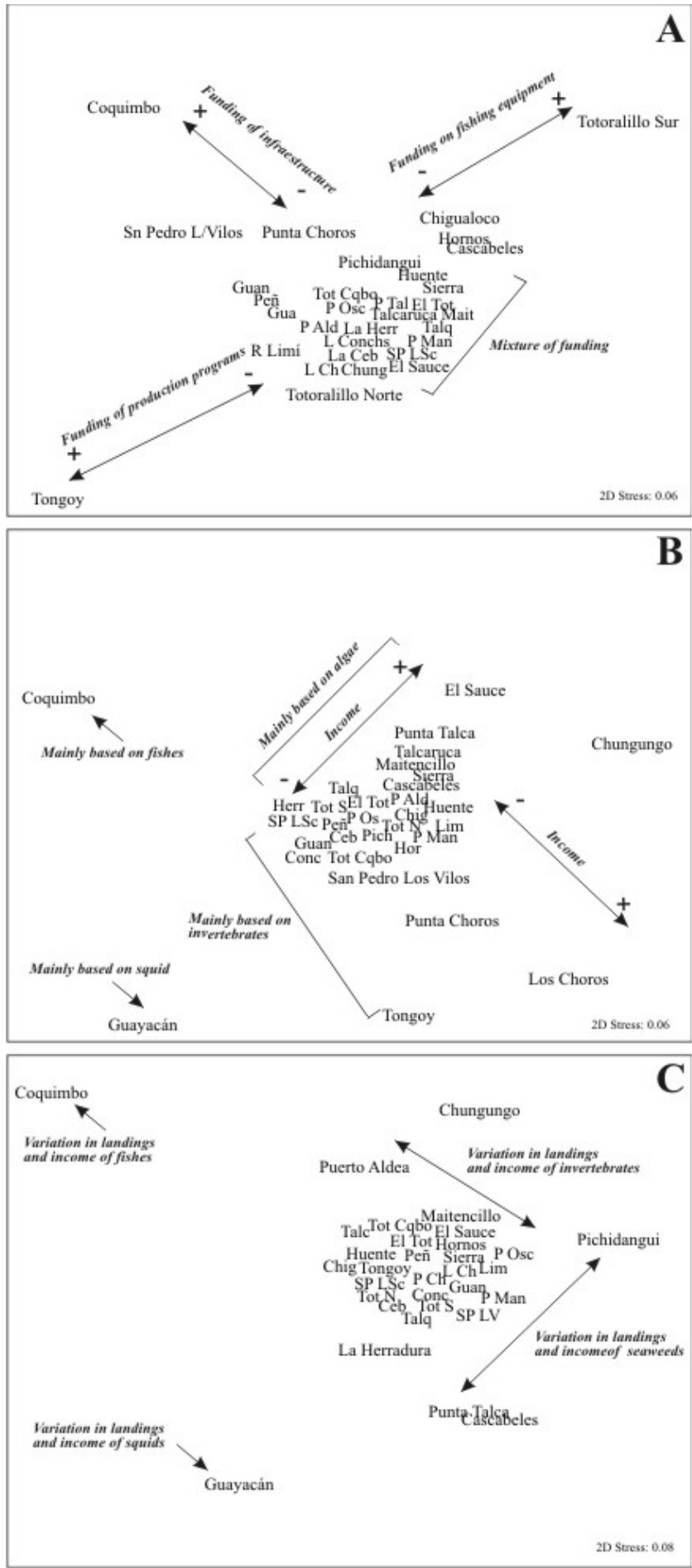


\section{CONCLUSION}

Assumptions of linear relationships between inputs and outputs in small-scale fisheries are simplistic. In the cases explored here, despite subsidies being much higher than global averages, almost no effect on fisheries was detected, although living and working conditions probably improved for the fishermen themselves. Indeed, this study suggests that, provided that subsidies do not create incentives to improve fishing efficiency (bigger boats, bigger nets, etc.), the assumed detrimental effects of subsidies should not be presupposed. Greater attention therefore needs to be paid to the types of subsidies received and not just the management regimes associated with subsidies.

With some notable exceptions (e.g., Yagi et al. 2009), the dearth of empirical studies demonstrating the assumed relationship between subsidies and over-exploitation is a concern. Far more effort needs to be put into monitoring and evaluating the outcomes of subsidies in small-scale fisheries, taking note of both management regimes and the type of subsidies received. At present, the ways in which state agencies conduct their reporting and analysis of funding cycles impedes our ability to fully understand these outcomes. These reports focus overwhelmingly on the amount of money spent and implementation according to predetermined log-frames. Reporting generally takes place within single "administrative years," precluding long-term monitoring and evaluation of the outcomes. More effective means need to be sought to monitor and evaluate the outcomes of subsidies. These outcomes are inherently difficult to monitor and evaluate due to the difficulties involved in assigning causality to identified trends. Identifying indicators for both the social and the ecological domains of fisheries and then matching the tempo of monitoring to the tempo of change in these variables is a major challenge. Of particular concern should be a deeper understanding of changes in livelihoods, based on more inclusive indices than income alone.

Responses to this article can be read online at: http://www.ecologyandsociety.org/voll6/iss3/art17/ responses/

\section{Acknowledgments:}

To obtain the information used in this paper, the aid of Mr. Javier Chávez (in charge of the Artisanal Fisheries Department), Mr. Ronaldo Rocco (in charge of landing statistics), and Mr. Gerardo Cerda (Fisheries Administration Department), all three from the regional office of the National Fisheries Service (Coquimbo, Chile), was essential. Similarly, we are grateful for the information of the Fondo de Fomento de la Pesca Artesanal, provided by its head, Mr. Guillermo Rivera. Similarly, Mrs. Cristina Zepeda (Technical Coordinator of the SERCOTEC-MAS REGION Fond, La Serena, Chile) provided the information regarding projects funded by the Mas Region program (an EU-funded project). To all of them, our thanks. This work was funded by Proyecto Fondef D05I10410, led by Maria Lourdes Campos, Departamento de Psicologia, Universidad de La Serena. We are very grateful for the opportunity to have been part of this project and the diverse interesting interactions that it produced.

\section{LITERATURE CITED}

Abdallah, P., and U. Sumaila. 2007. An historical account of Brazilian public policy on fisheries subsidies. Marine Policy 31:444-450.

Aguilar, A. 2000. The political economy of marine fisheries development in Peru, Chile and Mexico. Journal of Latin American Studies 32:503-527.

Agüero, M. 2007. Chile. Pages 453-464 in C. De Young, editor. Review of the state of world marine capture fisheries management: Pacific Ocean. FAO Fisheries Technical Paper No. 488/1. FAO, Rome, Italy. [online] URL: http://www.fao.org/docrep/010/ a1465e/a1465e00.htm.

Allison, E. H., and F. Ellis. 2001. The livelihoods approach and management of small-scale fisheries. Marine Policy 25:377-388.

Allison, E., and B. Horemans. 2006. Putting the principles of the Sustainable Livelihoods Approach into fisheries development policy and practice. Marine Policy 30:757-766. 
Andrade, C. 1997. El efecto perverso de los subsidios en la pesca artesanal. Chile Pesquero 98:23-26.

Béné, C. 2003. When fishery rhymes with poverty in small-scale fisheries. World Development 31 (6):949-975.

Béné, C. 2009. Are fishers poor or vulnerable? Assessing economic vulnerability in small-scale fishing communities. Journal of Development Studies 45:911-933.

Berkes, F., J. Colding, and C. Folke. 2003. Navigating social-ecological systems: building resilience for complexity and change. Cambridge University Press, Cambridge, UK.

Berkes, F., and C. Folke. 1998. Linking social and ecological systems: management practices and social mechanisms for building resilience. Cambridge University Press, Cambridge, UK.

Berkes, F., and D. Jolly. 2001. Adapting to climate change: social-ecological resilience in a Canadian Western Arctic community. Ecology and Society 5: 18. [online] URL: http://www.ecologyandsociety.org/ vol5/iss 2/art18/.

Chávez, J., and M. Tirado. 2008. Informe pesquero artesanal. Servicio Nacional de Pesca Región de Coquimbo.

Clarke, K. R., and R. M. Warwick. 1994. Change in marine communities: an approach to statistical analysis and interpretation. Plymouth Marine Laboratory, Plymouth, UK.

Defeo, O., and J. Castilla. 2005. More than one bag for the world fishery crisis and keys for comanagement successes in selected artisanal Latin American shellfisheries. Reviews in Fish Biology and Fisheries 15:265-283.

FAO. 1974. Draft report of the Senegal fisheries identification mission. FAO/IBRD Cooperative Programme Report, 26/74. FAO, Rome, Italy.

Gallardo, G. 2008. From seascapes of extinction to seascapes of confidence. Territorial use rights in fisheries in Chile: El Quisco and Puerto Oscuro. Co-Action Publishing, Aberystwyth, UK. [online] URL http://www.co-action.net/books/Gallardo.
Gelcich, S., G. Edwards-Jones, M. Kaiser, and E. Watson. 2005. Using discourses for policy evaluation: the case of marine common property rights in Chile. Society \& Natural Resources 18:377-391.

Gelcich, S., G. Edwards-Jones, M. Kaiser, and E. Watson. 2007. Heterogeneity in fishers' harvesting decisions under a marine territorial user rights policy. Ecological Economics 61:246-254.

Gelcich, S., J. Keiser, J. Castilla, and G. EdwardJones. 2008. Engagement in co-management of marine benthic resources influences environmental perceptions of artisanal fishers. Environmental Conservation 35:36-45.

Gibson, J., and S. Rozelle. 2003. Poverty and access to roads in Papua New Guinea. Economic Development and Cultural Change 52:159-185.

Grafton, Q., R Arnasonm, T. Bjørndal, D. Campbell, H. Campbell, C. Clark, R. Connor, D. Dupont, R. Hannesson, R. Hilborn, J. Kirkley, T. Kompas, D. Lane, G. Munro, S. Pascoe, D. Squires, S. Steinshamn, B. Turris, and Q. Weninger. 2006. Incentive-based approaches to sustainable fisheries. Canadian Journal of Fisheries and Aquatic Sciences 63:699-710.

Grynberg, R. 2003. WTO fisheries subsidies negotiations: implications for fisheries access arrangements and sustainable management. Marine Policy 27:499-511.

Hernandez, A., and W. Kempton. 2003. Changes in fisheries management in Mexico: effects of increasing scientific input and public participation. Ocean and Coastal Management 46:507-526.

Jacquet, J., and D. Pauly. 2008. Funding priorities: big barriers to small-scale fisheries. Conservation Biology 22:832-835.

Johannes, R. 2002. The renaissance of communitybased marine resource management in Oceania. Annual Review of Ecological Systems 33:317-340.

Kaczynski, M., and D. Fluharty. 2002. European policies in West Africa: who benefits from fisheries agreements? Marine Policy 26:75-93. 
Khan, A., R. Sumaila, R. Watson, G. Munro, and D. Pauly. 2006. The nature and magnitude of global non-fuel fisheries subsidies. Catching more bait: a bottom-up re-estimation of global fisheries subsidies. Fisheries Centre Research Reports 14:5-37.

Leiva, G., and J. Castilla 2002. A review of the world marine gastropod fishery: evolution of catches, management and the Chilean experience. Reviews in Fish Biology and Fisheries 11:283-300.

Medina, M., R. Ortiz, C. Salas, and L. Zamora, editors. 1997. Visión del sector pesquero artesanal: bases de una propuesta para su desarrollo. Fundación para la superación de la pobreza, Santiago, Chile.

Meltzoff, S., Y. Lichtensztajn, and W. Stotz. 2002. Competing visions for marine tenure and comanagement: genesis of marine management area system in Chile. Coastal Management 30:85-99.

Milazzo, M. 1998. Subsidies in world fisheries: a reexamination. World Bank technical paper, ISSN 0253-7494; no.406. Fisheries series.

Montoya, M. 2002. Análisis de las Inversiones realizadas en el sector Pesquero Artesanal entre 1992-1999. Gobierno de Chile. Subsecretaría de Pesca.

OECD. 2006. The financial support to fisheries: implications for sustainable development. OECD Publication, Paris, France.

Panayotou, T. 1982. Management concept for small-scale fisheries: economic and social aspects. FAO Fisheries Technical Paper 228.

Pauly, D. 1997. Small-scale fisheries in the tropics: marginality, marginalization and some implications for fisheries management. Pages 40-49 in E. K. Pikitch, D. D. Huppert, and M. P. Sissenwine, editors. Global trends: fisheries management. American Fisheries Society Symposium 20, Bethesda, Maryland.

Pauly, D., V. Christensen, G. Guénette, T. Pitcher, R. Sumaila, C. Walters, R. Watson, and D. Zeller. 2002. Towards sustainability in world fisheries. Nature 418:689-695.
Salas, S., R. Chuenpagdee, J. C. Seijo, and A. Charles. 2007. Challenges in the assessment and Management of small-scale fisheries in Latin America and the Caribbean. Fisheries Research 87:5-16.

Schrank, W. 2003. Introducing fisheries subsidies. FAO Fisheries Technical Paper 437.

Sen, A. K. 1999. Development as freedom. Oxford University Press, Oxford, UK.

Smith, I. 1979. A research framework for traditional fisheries. ICLARM Studies and Reviews (2): Manila, Philippines.

Soto, M. 2002. Inversión sectorial en la pesca artesanal IV región periodo 1996- 2001. Servicio Nacional de Pesca Región de Coquimbo.

Squires, D., Q. Grafton, M. Ferdous, and I. Haji. 1998. Where the land meets the sea: integrated sustainable fisheries development and artisanal fishing. University of California. Discussion paper 98-26.

Yagi, N., M. Ariji, and Y. Senda. 2009. A timeseries data analysis to examine effects of subsidies to fishery productions in Japan. Fisheries Science 75:3-11.

${ }^{[1]}(100+$ IPC $) \times$ value of funding $/ 100=$ corrected value

[2] The sanction value is a reference value of resources according to the market. These sanction values are set forth in the General Law of Fisheries and Aquaculture (1991). 